\title{
Prospective role for adenosine and adenosinergic systems in psychiatric disorders ${ }^{1}$
}

Interest in the role of adenosinergic systems in psychiatric illnesses stems from observations made of caffeine abuse. Chronic excessive consumption of the adenosine receptor antagonist, caffeine, has been reported to induce caffeinism, a syndrome characterized by symptoms of depression, hyperanxiety, increased frequency of psycho-physiological disorders, as well as possible degraded performance (Gilliland \& Bullock, 1983). Caffeinism has also been associated with many of the features of anxiety, depression and schizophrenia (Greden, 1974; Greden et al. 1978; Lutz, 1978; Mikkelsen, 1978). Additionally, enhanced blood levels of the purines, adenosine and/or adenosine triphosphate have been reported in both schizophrenic and depressed patients (Hansen, 1972) and psychiatric disorders have been noted as symptoms of congenital diseases involving defective purine metabolism (e.g. Lesch-Nyhan syndrome). Recent discoveries have also suggested that existing therapeutic compounds (e.g. carbamazepine and 9-amino-1,2,3,4 tetrahydroacride (THA)) as well as some substances of abuse (e.g. ethanol) and some behavioural therapies (e.g. sleep deprivation and light therapy) may interact with or modulate neuronal adenosine systems: these findings suggest that adenosinergic mechanisms may play a role in a number of psychiatric disorders.

The purine nucleoside, adenosine, fulfils a number of essential metabolic functions, such as a precursor role in the production of adenosine triphosphate (ATP) and other nucleotides. In addition, however, adenosine is also thought to play a key role in neuronal functioning via interactions with specific adenosine receptors, the activation or inactivation of which has been demonstrated to produce profound changes in neuronal functioning (Stone, 1981; Phillis \& Wu, $1981 a, b$; Dunwiddie 1985; Fredholm \& Dunwiddie, 1988).

Neuronal adenosine receptors have been well characterized and at least two distinct sub-types have been identified: adenosine $A_{1}$ and $A_{2}$ receptors. These receptor subtypes were initially thought to be linked to the enzyme adenylate cyclase, with either a negative (the $A_{1}$ receptor) or a positive (the $\mathrm{A}_{2}$ receptor) coupling influencing the production of the second messenger compound, cyclic adenosine monophosphate (cAMP) (van Calker et al. 1979; Londos et al. 1979; Bruns, 1980). Subsequently, the rank order of ligand potencies at these receptors has been used as a criterion for characterizing adenosine receptor subtypes, since not all $A_{1}$ or $A_{2}$ receptors thus characterized appear to be linked to adenylate cyclase (Hamprecht \& van Calker, 1985; Fredholm \& Dunwiddie, 1988). Pharmacological, physiological and anatomical criteria reveal these two receptor subtypes to be distinct (Stone, 1981; Dunwiddie, 1985) and able to be preferentially radiolabelled (Yeung \& Green, 1984). Employing radioligand binding, the relative affinities of adenosine receptor ligands for the $A_{1}$ and $A_{2}$ receptor sub-types have been well characterized (Bruns et al. 1986).

Compounds with selective affinities for adenosine receptors are widely consumed. The methylxanthines caffeine, theophylline and theobromine are present in coffee, tea, cola drinks, cocoa and chocolate, as well as in some common cold medications and appetite suppressant preparations (Gould et al. 1984; Uhde 1988). Although these methylxanthines are antagonists at adenosine receptors, they are not particularly potent in terms of their affinity for adenosine receptors; nor do they possess any great selectivity for receptor subtypes. Novel adenosine receptor antagonists have been developed and many of these are much more potent than the existing

' Address for correspondence: Dr Michael J. Durcan, Laboratory of Clinical Studies, National Institute on Alcohol Abuse and Alcoholism, Building 10, Rm 3C218, 9000 Rockville Pike, Bethesda, MD 20892, USA. 
methylxanthines. Some of these have a degree of selectivity for adenosine receptor subtypes (Bruns et al. 1986).

Adenosine itself is rapidly metabolized by adenosine deaminase and adenosine kinase and thus direct administration of adenosine is not particularly effective. However, a number of more stable adenosine analogues have been developed which are not readily metabolized. These analogues also vary in their potency and their receptor subtype selectivity (Bruns et al. 1986). The receptor subtype selectivity of the existing agonists and antagonists heavily favours the $A_{1}$ rather than the $A_{2}$ receptor, with relatively few compounds having greater selectivity for the $A_{2}$ over the $A_{1}$ receptor and those that do, do so only marginally (Bruns et al. 1986). A transport system for the re-uptake of released adenosine and other nucleotides is present on the extracellular membranes of many, if not all, cell types. Blockade of this system can increase the receptor availability of adenosine and a number of compounds, such as dipyridamole, nitrobenzylthioinosine, dilazep and mioflazine are thought to achieve their therapeutic effect by inhibiting adenosine uptake (Paterson et al. 1981, 1983; Clanachan \& Hammond, 1983; Deckert et al. 1988). Additionally, inhibitors of adenosine deaminase or adenosine kinase may be effective in raising adenosine levels.

Normal brain concentrations of adenosine have been estimated at about 1-10 micromolar but under conditions of anoxia or hypoxia levels of adenosine can increase dramatically (Berne $e t$ al. 1974). This, coupled to the general depressant action of adenosine (Phillis et al. $1979 a$; Hollins \& Stone, 1980), has led to the hypothesis that adenosine plays an important role in activity homeostasis serving as an endogenous neuroprotective compound, playing a role, for example, in limiting or reversing epileptic, ischaemic, anoxic or hypoglycaemic conditions (Dragunow et al. 1985; Dragunow \& Faull, 1988). Adenosine has also been suggested to play a role in physiological functions such as sleep, respiration and blood pressure (Synder et al. 1981 ; Yarbrough \& McGuffinClineschmidt, 1981; Dunwiddie \& Worth, 1982; Radulovacki et al. 1982). Increasingly, adenosine systems have been linked to psychiatric illnesses, either in terms of aetiology or therapeutics (Deckert et al. 1988; Williams \& Jarvis, 1988; Deckert \& Gleiter, 1989). The possible links between adenosinergic mechanisms and disorders, such as anxiety, sleep disorders, psychoses and affective disorders are discussed below. The aim, however, is to heighten awareness of these links rather than to provide a comprehensive review. Additionally, the possible future potential of adenosinergic compounds in psychiatric illness is discussed.

\section{ANXIETY DISORDERS}

The adenosine receptor antagonist caffeine produces an anxiogenic profile in experimental animals (File \& Hyde, 1979; Pellow et al. 1985; Boulenger et al. 1986; Lister 1987). In normal humans, caffeine in sufficient doses heightens anxiety (Charney et al. 1984; Uhde et al. 1984; Loke et al. 1985; Boulenger et al. 1987), induces increases in blood cortisol levels (Uhde et al. 1984) and can potentiate the effects of stress (Cobb, 1974; Lane, 1983). The anxiogenic effect of caffeine is however more pronounced in patients suffering from generalized anxiety disorder (Boulenger \& Uhde, 1982) or panic disorder (Boulenger et al. 1984; Charney et al. 1985; Roy-Byrne \& Uhde, 1988). Reductions in anxiety levels can be achieved in some patients by caffeine abstinence alone (Bruce \& Lader, 1989).

More indirect evidence for involvement in anxiety comes from adenosinergic modulation of benzodiazepine action (Phillis \& Wu, 1982). For example, diazepam can enhance the depressant effects of adenosine (Phillis, 1979). Also, benzodiazepine-induced reductions in neuronal firing rates can be reversed by the adenosine receptor antagonist, theophylline (Phillis et al. 1979b) and chronic treatment with diazepam desensitizes adenosine $\mathrm{A}_{2}$ receptors (Hawkins et al. $1988 b, c$ ). Additionally, benzodiazepines can inhibit adenosine uptake (Phillis et al. 1980; Morgan et al. 1983a, b; Phillis 1984a; Morgan \& Stone, 1986; Phillis \& O'Regan, 1988) and this may influence their anxiolytic profile. Furthermore, both central and peripheral benzodiazepine antagonists and the betacarboline 'inverse agonists' have adenosine receptor antagonist properties (Phillis \& O'Regan, 1987, 1988). 
Further evidence for a link between adenosinergic mechanisms and anxiety comes from studies of genetically distinct rat strains. Rats selectively bred for 'emotional reactivity' have significant differences in their adenosine receptor densities; the more emotional Maudsley Reactive strain showing significantly greater adenosine receptor binding sites per unit protein than the less emotional Maudsley Non-Reactive strain (Marangos et al. 1987a). Interestingly, the same group found no differences between the strains for benzodiazepine binding sites (Tamborska et al. 1986) contrary to previous findings (Robertson et al. 1978).

There is, however, little behavioural evidence to support an anxiolytic profile for adenosine agonists although they do possess anticonvulsive and sedative actions seen in more accepted anxiolytics, such as benzodiazepines. However, the often marked sedative actions of these compounds may mask any anxiolytic profile in most tests of anxiety. For example, Baldwin \& File (1989) report no detectable anxiolytic profile for 2-chloroadenosine, in a social interaction test in rats, but do note significant reductions in motor activity.

\section{SLEEP DISORDERS}

Methylxanthine-containing beverages inhibit sleep in humans, both by increasing the latency to sleep and reducing sleep time; the pattern of sleep is also disturbed causing a shortening of the latency to rapid eye movement (REM) sleep (Brezinova et al. 1975; Karacan et al. 1976; Revelle et al. 1980; Dews 1982; Synder \& Sklar 1984). However, doses of caffeine below $100 \mathrm{mg}$ (such as those found in tea and cola drinks) may not have significant influences on sleep patterns (Ginsburg \& Weintraub, 1976; Dews 1982; Murray, 1988) and tolerance may occur in heavy coffee drinkers (Goldstein \& Kaizer, 1969). In rats, caffeine causes increased wakefulness and reductions in total sleep time (both slow wave and REM sleep) (Radulovacki et al. 1982; Yanik et al. 1987). Also, REM sleep deprivation causes increases in adenosine $A_{1}$ receptors (Radulovacki 1985; Yanik \& Radulovacki, 1987), an effect which is also seen following chronic caffeine administration (Boulenger et al. 1983; Marangos et al. 1984; Hawkins et al. 1988a).

Adenosine agonists induce sedation and have therefore been suggested as possible sleepenhancing preparations. In experimental animals, the administration of adenosine agonists decreases wakefulness and increases total sleep time, particularly slow wave sleep (Radulovacki et al. 1984; Radulovacki, 1985). The analogues used were effective at relatively low concentrations and increasing the dose had no further effect or even diminished the effects. This has been used as evidence that the effects on sleep are mediated via the $A_{1}$ receptor, since the analogues are relatively more selective for this receptor (compared to the $A_{2}$ receptor) in this dose range; this is of interest since the hypomobilizing effects of adenosine analogues appears to be mediated by the $A_{2}$ rather than $A_{1}$ receptors (Spealman \& Coffin, 1986; Durcan \& Morgan 1989a, b). These compounds, unlike other sleep-inducing agents such as the benzodiazepines and barbiturates, do not reduce REM sleep and if anything enhance it (Radulovacki et al. 1984). In addition to adenosine analogues, S-adenosyl-L-homocysteine, which is broken down to adenosine and homocysteine, also enhances sleep (Sarda et al. 1989) as does deoxycoformycin, an adenosine deaminase inhibitor (Radulovacki et al. 1983; Virus et al. 1983). The adenosine transport inhibitor, mioflazine, also enhances sleep patterns in dogs and this effect can be antagonized by caffeine (Wauquier et al. 1987). The effects of mioflazine on sleep in rats were only apparent during the light phase of the circadian cycle (when the rats would normally sleep); this is of interest in light of reports of circadian variation in adenosine receptor density (Virus et al. 1984). Mioflazine is also reported to be an effective sleep promoter in human subjects suffering from sleep disturbance and compares well with the benzodiazepine, flunitrazepam (Hoppenbrouwers \& Vanden Bussche 1989).

\section{DISORDERS OF ATTENTION AND COGNITION}

In normal subjects of all ages caffeine has been demonstrated repeatedly to increase attention, vigilance, and cognitive functioning (Elkins et al. 1981 ; Rapoport et al. 1981 ; Lieberman et al. 1987; 
Pons et al. 1988; Swift \& Tiplady, 1988) and has been reported effective in increasing performance and decreasing lapses of attention in hyperkinetic children (Reichard \& Elder, 1977; Harvey \& Marsh, 1978). However, at least some hyperactive children respond to sympathomimetics to a greater extent than to caffeine (Conners, 1979). In this respect caffeine may bring about its therapeutic action by modulating monoamine neurotransmission, which has been extensively documented in studies performed in vitro (Fredholm, 1976; Clanachan et al. 1977; Harms et al. 1979; Michaelis et al. 1979).

One of the most promising therapeutic compounds in the treatment of Alzheimer's disease is the anticholinesterase compound 9-amino-1,2,3,4-tetrahydroacridine (THA), which has been reported to improve memory dramatically in Alzheimer's dementia (Summers et al. 1981, 1986). Consensus opinion is that THA may largely act by inhibiting cholinesterases (Drukarch et al. 1987; Nilsson et al. 1987). An anticholinesterase action of THA does not, however, seem likely to be a complete explanation of its effectiveness in Alzheimer's dementia, since THA is far more effective in treating Alzheimer's dementia than other anticholinesterases, suggesting that additional mechanisms may be involved in its therapeutic efficacy (Reiner \& McGeer, 1988); other studies suggest that THA may modulate neuronal levels of not only acetylcholine but also monoamines (Drukarch et al. 1988; Reiner \& McGeer, 1988). THA has also been reported recently to interact with adenosinergic systems and adenosine $A_{1}$ receptors. For example, in vitro studies of the inotropic effects of adenosine and 2-chloroadenosine reveal that 1-4 micromolar THA reversed the negative inotropic effects of these adenosinergic compounds and THA has also been demonstrated to be a weak competitor at adenosine $A_{1}$ receptors in guinea-pig brain (Freeman et al. 1988). Since in vitro studies reveal that adenosine and some of its more stable analogues can inhibit the release of acetylcholine and monoamines from neuronal preparations (Ginsborg \& Hirst, 1972; Harms et al. 1978, 1979; Michaelis et al. 1979), inhibition of adenosinergic modulation of acetylcholine or monoamine neurotransmitter release may play a role in the clinical effectiveness of THA in Alzheimer's dementias.

\section{PSYCHOTIC DISORDERS}

An antipsychotic potential for adenosine agonists may be indicated, in part, on the basis of the regional distribution of adenosine receptors. While $A_{1}$ receptors are located in many brain areas, the $\mathrm{A}_{2}$ subtype are largely restricted to dopamine-rich regions, such as the caudate putamen, nucleus accumbens and the olfactory tubercle (Premont et al. 1979; Bruns et al. 1980, 1986; Wojcik \& Neff, $1983 a, b)$. This has led to speculation that adenosinergic compounds may have antipsychotic potential, possibly as a consequence of modulation of dopamine release (Myers \& Pugsley, 1986), since these brain areas have also been implicated in antipsychotic drug action.

In vitro studies reveal that adenosine or its analogues can inhibit dopamine release (Harms $e t$ al. 1979; Michaelis et al. 1979) and desensitize dopamine receptors (Porter et al. 1988). Administration of adenosine analogues in vivo has been shown to influence dopamine metabolism in this region (Dunwiddie, 1985; Myers \& Pugsley, 1986) and bilateral injections of these analogues directly into the striatum are reported to depress locomotor activity (Barraco \& Bryant, 1987). Adenosine agonists also alter behaviours which are thought to be mediated by dopaminergic mechanisms and have been used as models of antipsychotic activity; for example, the inhibition of locomotor activity (Synder et al. 1981; Phillis et al. 1986; Durcan \& Morgan 1989a, b), ataxia (Geyer et al. 1982; Heffner et al. 1985), Sidman avoidance responding (Bridges et al. 1987) apomorphine-induced rotational behaviour (Fredholm et al. 1984) and the enhancement of prolactin release (Stewart \& Pugsley, 1985). The adenosine agonist, $\mathbf{N}^{6}$-(2,2-diphenylethyl)adenosine, compares favourably with haloperidol and thioridazine on these tests (Bridges et al. 1987). The adenosine receptor antagonist theophylline (in the form of aminophylline) blocks adenosine agonist-induced increases in prolactin release (Stewart \& Pugsley, 1985); theophylline, and its analogue 8-phenyl theophylline, both potentiate apomorphine-induced rotational behaviour (Fredholm et al. 1984). Additional evidence comes from reports that the neuroleptic compound, haloperidol, potentiates the R-phenylisopro- 
pyladenosine (R-PIA)-induced increase in prolactin secretion (Stewart \& Pugsley, 1985) whereas methylxanthine-containing beverages antagonize the behavioural effects of haloperidol (FoussardBlanpin \& Barbier, 1986). The adenosine receptor subtype involved in the modulation of dopamine release remains to be clarified; however, it would appear that compounds with higher affinities to the $A_{2}$ receptors as compared to $A_{1}$ receptors are more potent in suppressing behavioural phenomena related to dopaminergic activity, such as locomotor activity (Barraco \& Bryant, 1987; Durcan \& Morgan $1989 a, b)$.

The modulation of dopamine release not only suggests a role for adenosine agonists in antipsychotic therapy by inhibiting dopamine release, but also suggests that adenosine antagonists may be useful in movement disorders such as Parkinson's disease and tardive dyskinesia by virtue of their enhancement of dopamine release (Fuxe \& Ungerstedt, 1974).

\section{LESCH-NYHAN SYNDROME}

Lesch-Nyhan syndrome (Lesch \& Nyhan, 1964), which appears to result from a deficiency of the purine salvage mechanism, involving a defect in the gene encoding the enzyme hypoxanthineguanine phosphoribosyl transferase, also appears to be associated with changes in CNS monoamine turnover (Baumeister \& Frye, 1985). Thus, studies of CSF composition in Lesch-Nyhan boys reveal marked reductions in the levels of homovanillic acid and 3-methoxy-4-hydroxy-phenylethylene glycol and high levels of 5-hydroxyindoleacetic acid in CSF suggesting reduced dopamine and noradrenaline turnover and increased serotonin turnover (Jankovic et al. 1988). Neonatal lesioning of dopamine neurons with 6-hydroxy-dopamine in rats has been proposed as an animal model of the dopamine deficiency in Lesch-Nyhan syndrome (Breese et al. 1984). Such animals, which exhibit nucleoside and nucleotide levels within the normal range, have been reported to be supersensitive to the adenosine antagonist, theophylline (Criswell et al. 1988). Additionally, chronic administration of high doses of methylxanthines can induce self-injurious behaviour in rodents (Peters, 1967; Sakata \& Fuchimoto, 1973; Lloyd \& Stone, 1981). The adenosine agonists N-ethyl carboxamidoadenosine (NECA) or 2-chloroadenosine are reported to block 1-dopa or SKF 38393 (a direct acting $D_{1}$-dopamine agonist)-induced self-mutilation in this animal model (with relative $A_{1}$ and $A_{2}$ adenosine receptor potencies suggesting an adenosine $A_{2}$-mediated action) (Criswell et al. 1988). Such data would suggest that adenosine agonists, and $A_{2}$ agonists such as NECA in particular, may be useful in ameliorating dopamine-mediated symptoms of Lesch-Nyhan syndrome.

\section{BIPOLAR AFFECTIVE DISORDERS}

A possible role for adenosine in bipolar affective disorders comes largely from circumstantial evidence linking adenosinergic mechanisms to some of the treatment strategies, such as electroconvulsive shock, sleep deprivation, lithium and tricyclic drug administration. Antidepressant drugs are reported to increase cyclic AMP via adenosinergic mechanisms (Sattin et al. 1978; Sattin $1981 a, b)$, whereas lithium is reported to inhibit adenosine-induced increases in cyclic AMP (Ebstein et al. 1978; Hamburger-Bar et al. 1986). Electro-convulsive shock (ECS) increases $A_{1}$ receptors (Newman et al. 1984; Gleiter et al. 1989), although these changes are not accompanied by any changes in seizure threshold to caffeine (Gleiter et al. 1988); REM sleep deprivation also increases $A_{1}$ receptors (Radulovacki, 1985). However, carbamazepine treatment is the most extensively investigated in relation to adenosine.

Carbamazepine (Tegretol) has a number of clinical actions including antidepressant and antimanic properties (Ballenger \& Post, 1980; Post et al. 1984; Stromgren \& Boller, 1985; Ballenger, 1988; Botte \& Charles, 1988) and these may be superior to other treatments for certain sub-populations of depressive patients (e.g. rapid cycling illnesses (Post, 1989)). Although it possesses a primary tricyclic chemical structure, carbamazepine is reported to bind competitively to neuronal adenosine receptors both in rodent (Skerritt et al. 1982, 1983; Weir et al. 1984; Fujiwara et al. 1986; Marangos et al. 1987c) and in human post-mortem (Dodd et al. 1986) brain membranes, possibly binding 
largely to the adenosine $A_{1}$ receptor (Weir et al. 1984; Clark \& Post, 1989). It has been suggested that interactions at adenosine receptors may contribute to, or even underlie, the therapeutic efficacy of carbamazepine (Skerritt et al. 1982, 1983; Hood et al. 1983; Weir et al. 1984; Fujiwara et al. 1986; Dodd et al. 1986; Marangos et al. $1987 \mathrm{~b}$ ). The principal rationale for this assertion is that carbamazepine inhibits in vitro ligand binding to adenosine receptors at concentrations within the therapeutically effective plasma concentration range (Skerritt et al. 1982, 1983), although it should be pointed out that these in vitro binding studies are conducted at ambient temperatures considerably below body temperature and may not reflect in vivo affinities or binding characteristics. Furthermore, drug interaction, thermodynamic and chronic drug treatment studies of the effect of carbamazepine on adenosine ligand binding have been interpreted as revealing antagonist properties for carbamazepine (Skerritt et al. 1983; Marangos et al. 1987b, c; Daval et al. 1989), a contention that is supported by in vivo microiontophoretic studies of neuronal firing rate in rat brain (Phillis, 1984b). If adenosine receptors figure largely in the therapeutic efficacy of carbamazepine, then adenosine antagonism is a somewhat surprising efficacy, since it also possesses potent anticonvulsant properties (Skerritt et al. 1982, 1983; Weir et al. 984), while many other adenosine receptor antagonists exhibit convulsant activity (Richie, 1975; Morgan et al. 1989) and adenosine itself potently depresses neuronal activity (Hollins \& Stone, 1980; Stone, 1981; Phillis et al. 1979a). Also, the adenosine antagonists caffeine and theophylline, at high but sub-convulsive doses, do not alter the anticonvulsant potency of carbamazepine on amygdala-kindled seizures (Weiss et al. 1985) nor do they appear effective in affective disorders, in fact, high doses of caffeine have been reported to exacerbate depressive mood (Veleber \& Templer, 1984). Further investigations are required to determine the role of adenosine receptors in the therapeutic efficacy of carbamazepine.

\section{ALCOHOL AND DRUG ABUSE}

Investigations of interactions of adenosinergic compounds with the behavioural effects of ethanol have focused largely on methylxanthine adenosine receptor antagonists. Ethanol does not appear to affect adenosine levels per se (Phillis et al. 1980b; Clark \& Dar 1988a); however, ethanol administration does cause an increase in $\mathrm{A}_{1}$ adenosine receptor binding sites (Dar et al. 1983; Clark \& Dar, 1988b), thus suggesting that it is sensitivity to adenosine or adenosinergic drugs, rather than changes in adenosine levels, which may account for the reported interactions with ethanol.

Ethanol administration causes a number of physiological and behavioural effects and some, but not all, of these can be attenuated by adenosine antagonists (Dar et al. 1983; 1987; Clark \& Dar, 1988 b; Dar, 1988; Dar \& Wooles, 1988; Hilakivi et al. 1989). Adenosine receptor agonists such as $\mathrm{N}^{6}$ R-phenylisopropyladenosine (R-PIA) and uptake blockers such as dipyridamole and dilazep have been conversely reported to potentiate the sedative and motor incoordinating effects of ethanol (Dar et al. 1983; Clark \& Dar, 1988b). Further evidence for a link between the effects of ethanol and adenosinergic mechanisms comes from reports that mice selectively bred for sensitivity to ethanol show differential behavioural sensitivity to adenosinergic drugs (Proctor \& Dunwiddie, 1984; Fredholm et al. 1985; Proctor et al. 1985) and differences in numbers of adenosine $A_{1}$ receptors (Fredholm et al. 1985).

Human studies have not provided any clear indication as to the ethanol antagonizing properties of methylxanthines despite the widespread belief in the sobering properties of coffee. These studies have suffered from problems of prior experiences with ethanol or methylxanthine-containing beverages, the doses of each of the drugs used, intervals between their administration, and the types of test used. Some studies have suggested that caffeine can antagonize some, but not all ethanolinduced impairments (Forney \& Hughes, 1965; Franks et al. 1975; Linnoila \& Mattila, 1981) while others have found no significant antagonistic effect (Newman \& Newman, 1956; Oborne \& Rodgers, 1983). There is little evidence to support the notion of an amethystine effect of caffeine (Nash, 1966; Fubin \& Nicastro, 1988). Post-ethanol administration of aminophylline (which breaks down to theophylline and ethylenediamine) has also been shown to reduce ethanol's effects on the 
EEG and motor coordination (Alkana et al. 1977); however, the ethylenediamine (a structural analogue of $\mathrm{GABA}$ ) may be playing a role in these effects.

Adenosinergic mechanisms may also be implicated in opiate dependence. Methylxanthines can reverse some of the acute effects of opiates (Ho et al. 1973; Stone \& Perkins, 1979; Perkins \& Stone, 1980; Ahlijanian \& Takemori, 1985) and can precipitate withdrawal signs in morphine-dependent rhesus monkeys (Aceto et al. 1978). The effects of methylxanthines on the development of morphine tolerance and dependence is, however, less clear with reports of both increases (Ho et al. 1975; Francis et al. 1976; Hammond et al. 1976) or decreases (Matsuda, 1970; Brailowsky et al. 1981; Ahlijanian \& Takemori, 1986a). Morphine tolerant or dependent mice are also reported to be more sensitive to drugs acting at adenosine receptors (Ahlijanian \& Takemori, 1986 b).

\section{PSYCHIATRIC POTENTIAL OF ADENOSINERGIC DRUGS}

It is clear from the above discussion that the modulation of adenosinergic systems may play a role in the treatment of a number of psychiatric disorders. However, it is equally clear that the evidence is, in many instances, largely circumstantial and in some cases rather circular. While drugs acting on adenosinergic mechanisms provide no 'magic bullets', they may, as a consequence of adenosine's modulatory action on neuro-transmitter systems, provide some therapeutic potential either directly or adjunctively with other treatment modalities.

Existing adenosine receptor agonists and antagonists are, however, unlikely to be of major use in psychiatric disorders. For example, known adenosine agonists are potent hypotensive agents (Vapaatalo et al. 1975; Phillis \& Wu, 1981 b; Berne et al. 1983) and produce marked sedation (Dunwiddie \& Worth, 1982; Phillis et al. 1986) and bradycardia (Barraco et al. 1984, 1986), as well as proconvulsant actions (Morgan et al. 1989). Conversely, side effects of antagonists, such as convulsant properties (Richie, 1975) and tachycardia (Belardinelli et al. 1983), equally detract from therapeutic usefulness. Such adverse actions may not be insuperable: adenosine receptors are heterogeneous, with at least two receptor sub-types currently established (Stone, 1981; Dunwiddie, 1985). At present only very $A_{1}$ receptor subtype selective compounds have been developed; very $A_{2}$ selective compounds may well be developed in the near future. Additionally, other adenosine receptor subtypes may be uncovered, for example, an adenosine $A_{3}$ receptor has been proposed (Riberio \& Sebastiao, 1986). Compounds which have greater selectivity for non- $A_{1}$ receptor subtypes may possess fewer adverse side effects and thus cause a reappraisal of the role of adenosinergic systems in psychiatric disorders. In particular, the fact that adenosinergic systems are capable of inhibiting the release of a wide array of neurotransmitters (Dunwiddie, 1985; Fredholm \& Dunwiddie, 1988) suggests that adenosinergic systems may modulate a common excitationcoupled release mechanism. Although this might appear a very non-specific action, the very discrete distribution of adenosine $A_{2}$ receptors (largely in the striatum) may give $A_{2}$ receptor selective ligands localized actions; this may be especially relevant in the treatment of illnesses associated with disruptions of the nigro-striatal axis.

Of the treatment modalities at present in use which have been demonstrated to interact with adenosine receptors (such as carbamazepine, tetrahydroacride, or ECT) there is no strong evidence to suggest that adenosinergic modulation is a primary action. The main problem here is that little is known about the therapeutically important mode of action of these treatments. The major role of existing adenosinergic compounds in psychiatric disorders may be in further delineating brain mechanisms associated with those disorders. Their use as pharmacological tools may be extremely important in elucidating the action of currently employed treatments. They may also point the way to more effective pharmaceutical treatment modalities involving either adenosinergic or nonadenosinergic mechanisms. 


\section{REFERENCES}

Aceto, M. D., Carchman, R. A., Harris, L. S. \& Flora, R. E. (1978). Caffeine elicited withdrawal signs in morphine-dependent rhesus monkeys. European Journal of Pharmacology 50, 203-207.

Ahlijanian, M. K. \& Takemori, A. E. (1985). Effects of (-)-N $\mathbf{N}^{6}-(\mathrm{R}$ phenylisopropyl)-adenosine (PIA) and caffeine on nociception and morphine-induced analgesia, tolerance and dependence in mice. European Journal of Pharmacology 112, 171-179.

Ahlijanian, M. K. \& Takemori, A. E. (1986a). The effect of chronic administration of caffeine on morphine-induced analgesia, tolerance and dependence in mice. European Journal of Pharmacology 120, 25-32.

Ahlijanian, M. K. \& Takemori, A. E. (1986b). Changes in adenosine receptor sensitivity in morphine-tolerant and -dependent mice. Journal of Pharmacology and Experimental Therapeutics 236, 615-620.

Alkana, R. L., Parker, E. S., Cohen, E. B., Birch, H. \& Noble, E. P. (1977). Reversal of ethanol intoxication in humans, an assessment of the efficacy of 1-dopa, aminophylline and ephedrine. Psychopharmacology 55, 203-221.

Baldwin, H. A. \& File, S. E. (1989). Caffeine-induced anxiogenesis: the role of adenosine, benzodiazepine and noradrenergic receptors. Pharmacology, Biochemistry and Behavior 32, 181-186.

Ballenger, J.C. (1988). The use of anticonvulsants in manicdepressive illness. Journal of Clinical Psychiatry 49, 21-25.

Ballenger, J. C. \& Post, R. M. (1980). Carbamazepine (Tegretol) in manic-depressive illness: a new treatment. American Journal of Psychiatry 137, 782-790.

Barraco, R. A. \& Bryant, S. (1987). Depression of locomotor activity following bilateral injections of adenosine analogs into the striatum of mice. Medical Science Research 15, 421-422.

Barraco, R. A., Aggarwal, A. K., Phillis, J. W., Moron, M. A. \& Wu, P. H. (1984). Dissociation of the locomotor and hypotensive effects of adenosine analogues in the rat. Neuroscience Letters 48, 139-144.

Barraco, R. A., Phillis, J. W., Campbell, W. R., Marcantonio, D. R. \& Salah, R. S. (1986). The effects of central injections of adenosine analogs on blood pressure and heart rate in the rat. Neuropharmacology 25, 675-680.

Baumeister, A. A. \& Frye, G. D. (1985). The biochemical basis of the behavioral disorder in the Lesch-Nyhan syndrome. Neuroscience and Biobehavioral Review's 9, 169-178.

Belardinelli, L., West, A., Crampton, R. \& Berne, R. M. (1983). Chronotropic and dromotropic effects of adenosine. In. Regulatory Function of Adenosine (ed. R. M. Berne, T. W. Rall and R. Rubio), pp. 377-398. Martinus Nijhoff: The Hague.

Berne, R. M., Rafael, R. \& Cornish, R. R. (1974). Release of adenosine from ischemic brain. Circulation Research 35, 262-271.

Berne, R. M., Winn, R., Knabb, R. M., Ely, S. W. \& Rubio, R. (1983). Blood flow regulation by adenosine in heart, brain and skeletal muscle. In Regulatory Function of Adenosine (ed. R. M. Berne, T. W. Rall and R. Rubio), pp. 293-317. Martinus Nijhoff: The Hague.

Botte, L. \& Charles, G. (1988). The clinical use of carbamazepine. Review of literature and personal results. Acta Psychiarica Belgica 88, $181-194$.

Boulenger, J-P., \& Uhde, T. W. (1982). Caffeine consumption and anxiety: preliminary results of a survey comparing patients with anxiety disorder and normal controls. Psychopharmacoiogy Bulletin 18, 53-57.

Boulenger, J.-P., Patel, J., Post, R. M., Parma, A. \& Marangos, P. J. (1983). Chronic caffeine consumption increases the number of brain adenosine receptors. Life Sciences 32, 1135-1142.

Boulenger, J-P., Uhde, T. W., Wolff, E. A. \& Post, R. M. (1984). Increased sensitivity to caffeine in patients with panic disorder: preliminary evidence. Archives of General Psychiatry 41, $1067-1071$.

Boulenger, J-P., Marangos, P. J., Zander, K. J. \& Hanson, J. (1986). Stress and caffeine: effects on central adenosine receptors. Clinical Neuropharmacology 9, 79-83.

Boulenger, J-P., Salem, N., Marangos, P. J. \& Uhde, T. W. (1987).
Plasma adenosine levels: measurement in humans and relationship to the anxiogenic effects of caffeine. Psychiatry Research 21, 247-255.

Brailowsky, S., Guerrero-Munoz, F., Lujan, M., \& Shkurovich, M. (1981). Morphine-theophylline interaction: antagonism or facilitation? British Journal of Pharmacology 73, 887-892.

Breese, B. R., Baumeister, A. A., McGown, T. J., Emerick, S. G., Frye, G. D. \& Mueller, R. A. (1984). Neonatal-6-hydroxydopamine treatment : model of susceptibility for self mutilation in the LeschNyhan syndrome. Pharmacology, Biochemistry and Behavior 21, 459-461.

Brezinova, V., Oswald, I. \& Loudon, J. (1975). Two types of insomnia : too much waking and not enough sleep. British Journal of Psychiatry 126, 439-445.

Bridges, A. J., Moos, W. H., Szotek, D. L., Trivedi, B. K., Bristol, J. A., Heffner, T. G., Bruns, R. F. \& Downs, D. A. (1987). N6 $-(2,2-$ diphenylethyl) adenosine, a novel adenosine receptor agonist with antipsychotic-like activity. Journal of Medical Chemistry 30 , 1709-1711.

Bruce, M. S. \& Lader, M. (1989). Caffeine abstention in the management of anxiety disorders. Psychological Medicine 19, 211-214.

Bruns, R. F. (1980). Adenosine receptor activation in human fibroblasts: nucleoside agonists and antagonists. Canadian Journal of Physiology and Pharmacology 58, 673-691.

Bruns, R. F., Daly, J. W. \& Synder, S. H. (1980). Adenosine receptors in brain membranes: binding of ${ }^{3} \mathrm{H}-\mathrm{N}^{6}$-cyclohexyladenosine and ${ }^{3} \mathrm{H}$-1,3-diethyl-8-phenylxanthine. Proceedings of the National Academy of Sciences USA 77, 5541-5551.

Bruns, R. F., Lu, G. H. \& Pugsley, T. A. (1986). Characteristics of the $A_{2}$ adenosine receptor labelled by ${ }^{3} \mathrm{H}-\mathrm{NECA}$ in rat striatal membranes. Molecular Pharmacology 29, 331-346.

Charney, D. S., Galloway, M. P. \& Heninger, G. R. (1984). The effects of caffeine on plasma MHPG, subjective anxiety, autonomic symptoms and blood pressure in healthy humans. Life Sciences 35, $135-144$.

Charney, D. S., Heninger, G. R. \& Jatlow, P. I. (1985). Increased anxiogenic effects of caffeine in panic disorders. Archives of General Psychiatry 42, 233-243.

Clanachan, A. S. \& Hammond, J. R. (1983). Drug interactions with the CNS nucleoside transport system. British Journal of Pharmacology 80, 625P.

Clanachan, A. S., Johns, A. \& Paton, D. M. (1977). Presynaptic inhibitory actions of adenine nucleotides and adenosine on neurotransmission in the rat vas deferens. Neuroscience 2, 597-602.

Clark, M. \& Dar, M. S. (1988a). The effects of various methods of sacrifice and of ethanol on adenosine levels in selected areas of rat brain. Journal of Neuroscience Methods 25, 243-249.

Clark, M. \& Dar, M. S. (1988 b). Mediation of acute ethanol-induced motor disturbances by cerebellar adenosine in rats. Pharmacology, Biochemistry and Behaviour 30, 155-161.

Clark, M. \& Post, R. M. (1989). Carbamazepine, but not caffeine, is highly selective for adenosine $A_{1}$ binding sites. European Journal of Pharmacology 164, 399-401.

Cobb, S. (1974). Physiologic changes in men whose jobs were abolished. Journal of Psychosomatic Research 18, 245-258.

Conners, C. K. (1979). The acute effects of caffeine on evoked responses, vigilance, and activity level of hyperkinetic children. Journal of Abnormal Child Psychology 7, 145-151.

Criswell, H., Mueller, R. A. \& Breese, G. R. (1988). Assessment of purine-dopamine interactions in 6-hydroxydopamine-lesioned rats: evidence for pre- and postsynaptic influence by adenosine. Journal of Pharmacology and Experimental Therapeutics 244, 493-500.

Dar, M.S. (1988). The biphasic effects of centrally and peripherally administered caffeine on ethanol-induced motor incoordination in mice. Journal of Pharmacy and Pharmacology 40, 482-487.

Dar, M. S. \& Wooles, W. R. (1988). Effect of chronically administered methylxanthines on ethanol-induced motor incoordination in mice. Life Sciences 39, 1429-1437.

Dar, M. S., Mustafa, S. J. \& Wooles, W. R. (1983). Possible role of 
adenosine in the CNS effects of ethanol. Life Sciences 33, $1363 \cdot 1374$.

Dar, M. S., Jones, M., Close, G., Mustafa, S. J. \& Wooles, W. R. (1987). Behavioural interactions of ethanol and methylxanthines. Psychopharmacology $91,1-4$.

Daval, J. L., Deckert, J., Weiss, S. R., Post, R. M. \& Marangos, P. J. (1989). Up-regulation of adenosine $A$, receptors and forskolin binding sites following chronic treatment with carbamazepine: a quantitive autoradiographic study. Epilepsia 30, 26-33.

Deckert. J. \& Gleiter, C. H. (1989). Adenosinergic psychopharmaceuticals? Trends in Pharmacological Sciences 10, 99-100.

Deckert, J., Morgan, P. F. \& Marangos, P. J. (1988). Adenosine uptake site heterogeneity in mammalian CNS? Uptake inhibitors as probes and potential neuropharmaceuticals. Life Sciences $\mathbf{4 2}$, 13311345.

Dews, P. B. (1982). Caffeine. Annual Review of Nutrition 2, 323-341. Dodd, P. R., Watson, W. E. \& Johnston, G. A. (1986). Adenosine receptors in post-mortem human cerebral cortex and the effect of carbamazepine. Clinical and Experimental Pharmacology and Physiology 13, 711-722.

Dragunow, M. \& Faull, R. L. M. (1988). Neuroprotective effects of adenosine. Trends in Pharmacological Sciences 9, 193-194.

Dragunow, M., Goddard, G. V. \& Laverty, R. (1985). Is adenosine an endogenous anticonvulsant? Epilepsia 26, 480-487.

Drukarch, B., Kits, K. S., Van der Meer, E. G., Lodder, J. C. \& Stoof, J. C. (1987). 9-amino-1,2,3,4-tetrahydroacride (THA), an alleged drug for treatment of Alzheimer's disease, inhibits acetylcholinesterase activity and slow outward $\mathrm{K}^{+}$current. European Journal of Pharmacology 141, 153-157.

Drukarch, B., Leysen, J. E. \& Stoof, J. C. (1988). Further analysis of the neuropharmacological profile of 9-amino-1,2,3,4-tetrahydroacride (THA), an alleged drug for treatment of Alzheimer's disease. Life Sciences 42, 1011-1017.

Dunwiddie, T. V. (1985). The physiological role of adenosine in the central nervous system. International Review of Neurobiology 27. 63139.

Dunwiddie, T. V. \& Worth, T. (1982). Sedative and anticonvulsant effects of adenosine analogs in mouse and rat. Journal of Pharmacology and Experimental Therapeutics 220, 70-76.

Durcan, M. J. \& Morgan, P. F. (1989a). Evidence for adenosine $A_{2}$ receptor involvement in the hypomobility effects of adenosine analogues in mice. European Journal of Pharmacology 168, 285290.

Durcan, M. J. \& Morgan, P. F. $\quad(1989 b)$. NECA-induced hypomotility in mice: evidence for a predominantly central site of action. Pharmacology, Biochemistry and Behavior 32, 487-490.

Ebstein, R. P., Reches, A. \& Belmaker, R. H. (1978). Lithium inhibition of the adenosine-induced increase of adenylate cyclase activity. Journal of Pharmacy and Pharmacology 30, 122-123.

Elkins, R. N., Rapoport, J. L., Zahn, T. P., Buchsbaum, M. S., Weingarter, H., Kopin, I. J., Langer, D. \& Johnson, C. (1981). Acute effects of caffeine on normal prepubertal boys. American Journal of Psychiarry 138, 178-183.

File, S. E. \& Hyde, J. R. G. (1979). A test of anxiety that distinguishes between the actions of benzodiazepines and those of other minor tranquilizers and of stimulants. Pharmacology, Biochemistry and Behavior 11, 65-69.

Forney, R. B. \& Hughes, F. W. (1965). Effect of caffeine and alcohol on performance under stress audiofeedback. Quarterly Journal of Studies on Alcohol 26, 206-212.

Foussard-Blanpin, O.\& Barbier, D. (1986). The influence of tea and caffeine on the behavioral effects of haloperidol in mice. Annales Pharmaceutiques Francaises 44, 233-241.

Francis, D. L., Cuthbert, N. J., Dinneen, L. C., Schneider, C. \& Collier, H. O. J. (1976). Methylxanthine-accelerated opiate dependence in the rat. In Opiates and Endogenous Peptides (ed. $\mathrm{H}$. Kosterlitz), pp. 177-184. Elsevier: Amsterdam.

Franks, H. M., Hagedorn, H., Hensley, V. R., Hensley, W. J. \& Starmer, G. A. (1975). Effect of caffeine on human performance, alone and in combination with ethanol. Journal of Studies on Alcohol 37, 284-297.
Fredholm, B. B. (1976). Release of adenosine-like material from isolated perfused dog adipose tissue following sympathetic nerve stimulation and its inhibition by adrenergic alpha receptor blockade. Acta Physiologica Scandinavica 96, 422-430.

Fredholm, B. B. \& Dunwiddie, T. V. (1988). How does adenosine inhibit transmitter release? Trends in Pharmacological Sciences 9 , 130-134.

Fredholm, B. B., Jonzon, B. \& Lindgren, E. (1984). Changes in noradrenaline release and in beta receptor number in rat hippocampus following long-term treatment with theophylline or L-phenylisopropyladenosine. Acta Physiologica Scandinavica 122 55-59.

Fredholm, B. B., Zahniser, N. R., Weiner, G. R., Proctor, W. R. \& Dunwiddie, T. V. (1985). Behavioral sensitivity to PIA in selectively bred mice is related to a number of $A$, receptors but not to cyclic AMP accumulation in brain slices. European Journal of Pharmacology 111, 133-136.

Freeman, S. E., Lau, W. M. \& Szilagyi, M. (1988). Blockade of a cardiac $\mathrm{K}^{+}$channel by tacrine: interactions with muscarinic and adenosine receptors. European Journal of Pharmacology 154, $59-65$.

Fubin, R. \& Nicastro, R. (1988). Can caffeine antagonize alcohol induced performance decrements in humans? Perceptual and Motor Skills 67, 375-391.

Fujiwara, Y.. Sato, M. \& Otsuki, S. (1986). Interaction of carbamazepine and other drugs with adenosine $\left(A_{1}\right.$ and $\left.A_{2}\right)$ receptors. Psychopharmacology 90, 332-335.

Fuxe, K. \& Ungerstedt, U. (1974). Action of caffeine and theophylline on supersensitive dopamine receptors: considerable enhancement of receptor response to treatment with dopa and dopamine agonists. Medical Biology 52, 58-54.

Geyer, H. M., Wilker, J., Spaulding, T., Cornfeldt, M., Brugger, S., Huger, F. \& Novick, W. (1982). N'-cyclohexyladenosine (CHA): some in vivo pharmacology. Federation Proceedings, American Society for Experimental Biology 41, 1071

Gilliland, K. \& Bullock, W. (1983). Caffeine as a potential drug of abuse. Advances in Alcohol and Substance Abuse 3, 53-73.

Ginsborg, B. L. \& Hirst, G. D. S. (1972). The effect of adenosine on the release of transmitter from the phrenic nerve of the rat. Journal of Physiology (London) 224, 629-645.

Ginsburg, R. \& Weintraub, M. (1976). Caffeine in the Sundown Syndrome'. Journal of Gerontology 31, 419-420.

Gleiter, C. H., Deckert, J. \& Nutt, D. J. (1988). Changes in caffeine seizure threshold after electroconvulsive shock. Psychopharmacology 95, 544-545.

Gleiter, C. H., Deckert, J., Nutt, D. J. \& Marangos, P. J. (1989) Electroconvulsive shock (ECS) and the adenosine neuromodulatory system: effect of single and repeated ECS on the adenosine $A_{1}$ and $A_{2}$ receptors, adenylate cyclase, and the adenosine uptake site. Journal of Neurochemistry 52, 641-646.

Goldstein, A. \& Kaizer, S. (1969). Psychotropic effects of caffeine in man. III. A questionnaire survey of coffee drinking and its effects in a group of housewives. Clinical Pharmacology and Therapeutics 10, 489-497.

Gould, R. J., Murphey, K. M. M., Katims, J. J. \& Snyder, S. H. (1984). Caffeine actions and adenosine. Psychopharmacology Bulletin 20, 436-440.

Greden, J. F. (1974). Anxiety or caffeinism: a diagnostic dilemma. American Journal of Psychiatry 131, 1089-1092.

Greden, J. F., Fontaine, P., Lubetsky, M. \& Chamberlin, K. (1978). Anxiety and depression associated with caffeinism among psychiatric inpatients. American Journal of Psychiatry 135 963-966.

Hamprecht, B. \& van Calker, D. (1985). Nomenclature of adenosine receptors. Trends in Pharmacological Sciences 6, 153-154.

Hamburger-Bar, R., Robert, M., Newman, M. \& Belmaker, R. H. (1986). Interstrain correlation between behavioral effects of lithium and effects on cortical cyclic AMP. Pharmacology, Biochemistry and Behavior 24, 9-13.

Hammond, M. D., Scheider, C. \& Collier, H. O. J. (1976). Induction of opiate tolerance in isolated guinea-pig ileum and its modification 
by drugs. In Opiates and Endogenous Peptides (ed. H. Kosterlitz), pp. 169-176. Elsevier: Amsterdam.

Hansen, O. (1972). Blood nucleoside and nucleotide studies in mental diseases. British Journal of Psychiatry 121, 341-350.

Harms. H. H., Wardeh, G. \& Mulder, A. H. (1978). Adenosine modulates depolarization-induced release of ${ }^{3} \mathrm{H}$-noradrenaline from slices of rat brain neocortex. European Journal of Pharmacology' 49, 305-308.

Harms, H. H., Wardeh, G. \& Mulder, A. H. (1979). Effect of adenosine depolarization-induced release of various radio-labelled neurotransmitters from slices of rat corpus striatum. Neuropharmacology 18, 577-580.

Harvey, D. H. \& Marsh, R. W. (1978). The effects of de-caffeinated coffee versus whole coffee on hyperactive children. Developmental Medicine and Child Neurology 20, 81-86.

Hawkins, M., Dugich, M. M., Porter, N. M., Urbancic, M. \& Radulovacki, M. (1988a). Effects of chronic administration of caffeine on adenosine $A_{1}$ and $A_{2}$ receptors in rat brain. Brain Research Bulletin 21, 479-482.

Hawkins, M., Pan, W., Stefanovich, P. \& Radulovacki, M. (1988b). Desensitization of adenosine $A_{2}$ receptors in the striatum of the rat following chronic treatment with diazepam. Neuropharmacology 27, $1131-1140$.

Hawkins, M., Pravica, M. \& Radulovacki, M. (1988c). Chronic administration of diazepam downregulates adenosine receptors in rat brain. Pharmacology, Biochemistry and Behavior 30, 303-308.

Heffner, T. G., Downs, D. A., Bristol, J. A., Bruns, R. F., Harrian, S. E., Moos, W. H., Sledge, K. L. \& Wiley, J. N. (1985). Antipsychotic-like effects of adenosine receptor agonists. Pharmacologist 27, 293.

Hilakivi, L. A., Durcan, M. J. \& Lister, R. G. (1989). Effects of caffeine on social behavior, exploration and locomotor activity: interactions with ethanol. Life Sciences 44, 543-553.

Ho, I. K., Loh, H. H. \& Leong Way, E. (1973). Cyclic adenosine monophosphate antagonism of morphine analgesia. Journal of Pharmacology and Experimental Therapeutics 185, 336-346.

Ho, I. K., Loh, K. K., Bhargava, H. N. \& Way, E. L. (1975). Effect of cyclic nucleotides and phosphodiesterase inhibition on morphine tolerance and physical dependence. Life Sciences 16, 1895-1900.

Hollins, C. \& Stone, T. W. (1980). Adenosine inhibition of gamma aminobutyric acid from slices of rat cerebral cortex. British Journal of Pharmacology 69, 107-112.

Hood, T. W., Siegfried, J. \& Hass, H. L. (1983). Analysis of carbamazepine actions in hippocampal slices of the rat. Cellular and Molecular Neurobiology 3, 213-222.

Hoppenbrouwers, M.-L. \& Vanden Bussche, G. (1989). Mioflazine, a nucleoside inhibitor: is it effective as a sleep promotor in humans? In Slow Wave Sleep: Physiological, Palhophysiological and Functional Aspects (ed. A. Wauquier, C. Dugovic and M. Radulovacki), pp. 301-309. Raven Press: New York.

Jankovic, J., Caskey, T. C., Stout, J. T. \& Butler, I. J. (1988). Lesch-Nyhan syndrome: a study of motor behavior and cerebrospinal fluid neurotransmitters. Annals of Neurology 23, 466-469.

Karacan, I., Thornby, J. I., Anch, M., Booth, G. H., Williams, R. L. \& Salis, P. J. (1976). Dose-related sleep disturbances induced by coffee and caffeine. Clinical Pharmacology and Therapeutics 20 , 682-689.

Lane, J. D. (1983). Caffeine and cardiovascular responses to stress. Psychosomatic Medicine 45, 447-451.

Lesch, M. \& Nyhan, W. L. (1964). A familial disorder of uric acid metabolism and the central nervous system. American Journal of Medicine 36, 561 . 570.

Lieberman, H. R., Wurtmam, R. J., Emde, G. G. Roberts, C. \& Coviella, I. L. (1987). The effects of low doses of caffeine on human performance and mood. Psychopharmacology 92, 308-312.

Linnoila, M. \& Mattila, M. J. (1981). How to antagonize ethanolinduced inebriation. Pharmacology and Therapeutics 15, 99-109.

Lister, R. G. (1987). The use of the plus-maze to measure anxiety in the mouse. Psychopharmacology 92, 180-185.

Lloyd, H. G. E. \& Stone, T. W. (1981). Chronic methylxanthine treatment in rats; a comparison of Wistar and Fisher 344 strains. Pharmacology, Biochemistry and Behavior 14, 827.830.

Loke, W. H., Hinrichs, J. V. \& Ghonheim, M. M. (1985). Caffeine and diazepam: separate and combined effects on mood, memory and psychomotor performance. Psychopharmacology 87, 344350.

Londos, C., Wolff, J. \& Cooper, D. M. F. (1979). Action of adenosine on adenylate cyclase. In Physiological and Regulatory Functions of Adenosine and Adenosine Nucleotides (ed. H. P. Baer and G. I. Drummond), pp. 271-281. Raven Press: New York.

Lutz, E. G. (1978). Restless legs, anxiety and caffeinism. Journal of Clinical Psychiatry 39, 691-698.

Marangos, P. J., Boulenger, J.-P. \& Patel, J. (1984). Effects of chronic caffeine on brain adenosine receptors: regional and ontogenetic studies. Life Sciences 34, 899-907.

Marangos, P. J., Insel, T. R., Montgomery, P. \& Tamborska, E. $(1987 a)$. Brain adenosine receptors in Maudsley Reactive and Non-Reactive rats. Brain Research 421, 6974.

Marangos, P. J., Montgomery, P., Weiss, S. R., Patel, J. \& Post, R. M. (1987b). Persistent up-regulation of brain adenosine receptors in response to chronic carbamazepine treatment. Clinical Neuropharmacology 10, 443448.

Marangos, P. J., Patel, J., Smith, K. D. \& Post, R. M. (1987c). Adenosine antagonist properties of carbamazepine. Epilepsia 28. 387-394.

Matsuda, K. (1970). Experimental studies on the effective procedure to inhibit the development of tolerance to and dependence on morphine. Arzniemittel-Forschung (Drug Research) 20, 1596 1604.

Michaelis, M. L., Michaelis, E. K. \& Myers, S. L. (1979). Adenosine modulation of synaptosomal dopamine release. Life Sciences 24 , 2083-2092.

Mikkelsen, E. J. (1978). Caffeine and schizophrenia. Journal of Clinical Psychiatry 39, 732736

Morgan, P. F. \& Stone, T. W. (1986). Inhibition by benzodiazepines and beta-carbolines of brief ( 5 seconds) synaptosomal accumulation of $\left[{ }^{3} \mathrm{H}\right]$-adenosine. Biochemical Pharmacology 10,1760 1762.

Morgan, P. F., Lloyd, H. G. E. \& Stone, T. W. (1983a). Benzodiazepine inhibition of adenosine uptake is not prevented by benzodiazepine antagonists. European Journal of Pharmacology 87, $121-126$.

Morgan, P. F., Lloyd, H. G. E. \& Stone, T. W. (1983b). Inhibition of adenosine accumulation by a CNS benzodiazepine antagonist (RO 15-1788) and a peripheral benzodiazepine receptor ligand (RO 054864). Neuroscience Letters $41,183188$.

Morgan, P. F., Deckert, J., Jacobson, K. A., Marangos, P. J. \& Daly, J. W. (1989). Potent convulsant actions of the adenosine receptor antagonist, xanthine amine congener (XAC). Life Sciences 45, 719-728.

Murray, J. B. (1988). Psychophysiological aspects of caffeine consumption. Psychological Reports 62, 575 587.

Myers, S. \& Pugsley, T. A. (1986). Decrease in striatal dopamine synthesis and metabolism in vivo by metabolically stable adenosine receptor agonists. Brain Research 375, 193-197.

Nash, H. (1966). Psychological effects \& alcohol-antagonizing properties of caffeine. Quarterly Journal of Studies on Alcohol 27, 727-734.

Newman, H. W. \& Newman, E. J. (1956). Failure of dexedrine and caffeine as practical antagonists of the depressant effect of ethyl alcohol in man. Quarterly Journal of Studies on Alcohol 17, 406-410.

Newman, M., Zohar, J., Kalian, M. \& Belmaker, R. H. (1984). The effects of chronic lithium and ECT on $A_{1}$ and $A_{3}$ adenosine systems in rat brain. Brain Research 291, 188 192.

Nilsson, L., Adem, A., Hardy, J., Winland, B. \& Norberg. A. (1987). Do tetrahydroaminoacride and physostigmine restore acetylcholine release in Alzheimer brains via nicotinic receptors? Journal of Neural Transmission 70, 357. 368.

Oborne, D. J. \& Rodgers, Y. (1983). Interactions of alcohol and caffeine on human reaction time. Aviation, Space and Environmental Medicine 54, 528-534.

Paterson, A. R. P., Kolassa, N. \& Cass, L. E. (1981). Transport of 
nucleoside drugs in animal cells. Pharmacology and Therapeutics 12, 515-536.

Paterson, A. R. P., Jakobs, E. S., Harley, E. R., Fu, N.-W., Robins, M. J. \& Cass, C. E. (1983). Inhibition of nucleoside transport. In Regulatory Function of Adenosine (ed. R. M. Berne, T. W. Rall and R. Rubio), pp. 293 313. Martinus Nijhoff: The Hague.

Pellow, S., Chopin, P., File, S. E. \& Briley, M. (1985). Validation of open:closed arm entries in an elevated plus-maze as a measure of anxicty in the rat. Journal of Neuroscience Methods 14, 149-167.

Perkins, M. N. \& Stone, T. W. (1980). Blockade of striatal neurone responses to morphine by aminophylline: evidence for adenosine mediation of opiate action. British Journal of Pharmacology 69, 131-137.

Peters, J. M. (1967). Caffeine-induced hemorrhagic automutillation. Archives internationales de pharmacodynamie et de therapié 169, 139.146.

Phillis, J. W. (1979). Diazepam potentiation of purinergic depression of central neurons. Canadian Journal of Physiology and Pharmacology 57, 432-435.

Phillis, J.W. $(1984 a)$. Adenosine's role in the central actions of benzodiazepines. Progress in Neuro-Psychopharmacology and Biological Psychiary 8, 495-502.

Phillis, J.W. (1984b). Interactions of the anticonvulants diphenylhydantoin and carbamazepine with adenosine on cerebral cortical neurons. Epilepsia 25, 765-772.

Phillis, J. W. \& O'Regan, M. H. (1987). Antagonism of adenosinergic depression of rat cortical neurones by beta-carboline derivatives. Medical Science Research 15, 1339-1340.

Phillis, J. W. \& O'Regan, M. H. (1988). The role of adenosine in the central actions of the benzodiazepines. Progress in Neuropsychopharmacology and Biological Psychiatry 12, 389-404.

Phillis, J. W. \& Wu, P. H. (1981a). The role of adenosine and its nucleotides in central synaptic transmission. Progress in Neurobiology 16, 187-239.

Phillis, J. W. \& Wu, P. H. $(1981 \mathrm{~b})$. The role of adenosine and its nucleotides in the central nervous system. In Physiology and Pharmacology of Adenosine Derivatives (ed. J. Daly, J. Kuruda, J. Phillis and M. Ui), pp. 219-236. Raven Press: New York.

Phillis, J. W. \& Wu, P. H. (1982). Adenosine and benzodiazepine action. In The Pharmacology of Benzodiazepines (ed. E. Usdin, P. Skolnick, J. F. Tallman, D. Greenblatt and S. M. Paul), pp. 497 507. Macmillan: London.

Phillis, J. W., Edstrom, J. P., Kostopoulos, A. K. \& Kirkpatrick, J. R. (1979a). Effects of adenosine and adenine nucleotides on synaptic transmission in the cerebral cortex. Canadian Journal of Physiology and Pharmacology 57, 1289-1310.

Phillis, J.W., Edstrom, J. P., Ellis, S. W. \& Kirkpatrick, J. R. $(1979 b)$. Theophylline antagonizes flurazepam-induced depression of cerebral cortical neurones. Canadian Journal of Physiology and Pharmacology 57, 917-920.

Phillis, J. W., Bender, A. S. \& Wu, P. H. (1980a). Benzodiazepines inhibit adenosine uptake in rat brain synaptosomes. Brain Research 195, 494-498.

Phillis, J.W., Jiang, Z. G. \& Chelack, B. J. $(1980 b)$. Effects of ethanol on acetylcholine and adenosine efflux from in vivo rat cerebral cortex. Journal of Pharmacy and Pharmacology 32, 871.872

Phillis, J. W., Barraco, R. A., DeLong, R. E. \& Washington, D. O. (1986). Behavioral characteristics of centrally administered adenosine analogs. Pharmacology, Biochemistry and Behavior 24, 263.270.

Pons, L., Trenque, T., Bielecki, M., Moulin, M., \& Potier, J. C. (1988). Attentional effects of caffeine in man: comparison with drugs acting upon performance. Psychiatry Research 23, 329-333.

Porter, N. M., Radulovacki, M. \& Green, R. D. (1988). Desensitization of adenosine and dopamine receptors in rat brain after treatment with adenosine analogs. Journal of Pharmacology and Experimental Therapeutics 244, 218-225.

Post, R. M. (1989). Emerging perspectives on valproate in affective disorders. Journal of Clinical Psychiatry 50 (suppl), 3-9.

Post, R. M., Ballenger, J. C., Uhde, T. W. \& Bunney, W. E., Jr.
(1984). Efficacy of carbamazepine in manic-depressive illness: implications for underlying mechanisms. In Neurobiology of Mood Disorders (ed. R. M. Post and J. C. Ballenger), pp. 777-816. Williams \& Wilkins: Baltimore.

Premont, J., Perez, M., Blanc, G., Tassin, J.-P., Thierry, A. M., Herve, D. \& Bockaert, J. (1979). Adenosine sensitive adenylate cyclase in rat brain homogenates: kinetic characteristics, specificity, topographical, subcellular and cellular distribution. Molecular Pharmacology 16, 790-804.

Proctor, W. R. \& Dunwiddie, T. V. (1984). Behavioral sensitivity to purinergic drugs parallels ethanol sensitivity in selectively bred mice. Science 224, 519-521.

Proctor, W. R., Baker, R. C. \& Dunwiddie, T. V. (1985). Differential CNS sensitivity to PIA and theophylline in long-sleep and shortsleep mice. Alcohol 2, 387-391.

Radulovacki, M. (1985). Role of adenosine in sleep in rats. Review's in Clinical and Basic Pharmacology 5, 327-339.

Radulovacki, M., Miletich, R. S. \& Green, R. D. (1982). N ${ }^{\sharp}$ (L. phenylisopropyl) adenosine (L-PIA) increases slow-wave sleep (S2) and decreases wakefulness in rats. Brain Research 246, 178-180.

Radulovacki, M., Virus, R. M., Djuricic-Nedelson, M. \& Green, R. D. (1983). Hypnotic effects of deoxycoformycin in rats. Brain Research 271, 392-395.

Radulovacki, M., Virus, R. M., Djuricic-Nedelson, M. \& Green, R. D. (1984). Adenosine analogs and sleep in rats. Journal of Pharmacology and Experimental Therapeutics 228, 268-274.

Rapoport, J. L., Elkins, R., Neims, A., Zahn, T. \& Berg, C. T (1981). Behavioral and autonomic effects of caffeine in normal boys. Developmental Pharmacology and Therapeutics 3, 74 82.

Reichard, C. C. \& Elder, S. T. (1977). The effects of caffeine on reaction time in hyperkinetic and normal children. American Journal of Psychiatry 134, 144-148.

Reiner, P. B. \& McGeer, E. G. (1988). THA increases action potential duration of central histamine neurons in vitro. European Journal of Pharmacology 155, 265-270.

Revelle, W., Humphreys, M. S., Simon, L. \& Gilliland, K. (1980). The interactive effect of personality, time of day and caffeine : a test of the arousal model. Journal of Experimental Psychology: General $109,1-31$

Ribeiro, J. A. \& Sebastiano, A. M. (1986). Adenosine receptors and calcium: basis for proposing a third $\left(\mathrm{A}_{3}\right)$ adenosine receptor. Progress in Neurobiology 26, 179-209.

Richie, J. M. (1975). Central nervous system stimulants: II. The methylxanthines. In The Pharmacological Basis of Therapeutics (ed. L. S. Goodman and A. Gilman), pp. 367-378. Macmillan: New York.

Robertson, H. A., Martin, I. L. \& Candy, J. M. (1978). Differences in benzodiazepine receptor binding in Maudsley Reactive and Maudsley Non-Reactive rats. European Journal of Pharmacology 50, 455-457.

Roy-Byrne, P. P. \& Uhde, T. W. (1988). Exogenous factors in panic disorder: clinical and research implications. Journal of Clinical Psychiatry 49, 56-61.

Sakata, T. \& Fuchimoto, H. (1973). Stereotyped and aggressive behavior induced by sustained high dose of theophylline in rats. Japanese Journal of Pharmacology' 23, 781 . 785.

Sarda, N., Gharib, A. \& Pacheco, H. (1989). S-adenosyl-Lhomocysteine, adenosine and L-homocysteine on sleep. In Slow Wave Sleep: Physiological, Pathophysiological and Functional Aspects (ed. A. Wauquier, C. Dugovic and M. Radulovacki), pp. 267-271. Raven Press: New York.

Sattin, A. $(1981 \mathrm{a})$. Adenosine as a mediator of antidepressant treatment. In Chemisms of the Brain (ed. R. Rodnight, $\mathrm{H}$. Bachelhard, and W. L. Stahl), pp. 265-275. Churchill Livingstone: Edinburgh.

Sattin, A. (1981 b). Adenosine as a mediator of central nervous system effects during psychiatric treatment. In Neuropharmacology of Central Nervous System and Behavioral Disorders (ed. G. C. Palmer), pp. 645-655. Academic Press: New York.

Sattin, A., Stone, T. W. \& Taylor, D. A. (1978). Biochemical and 
electropharmacological studies with tricyclic antidepressants in rat and guinea-pig cerebral cortex. Life Sciences 23, 2621-2626.

Skerritt, J. H., Davies, L. P. \& Johnston, G. A. R. (1982). A purinergic component in the anticonvulsant action of carbamazepine? European Journal of Pharmacology 82, 195-197.

Skerritt, J. H., Davies, L. P. \& Johnston, G. A. R. (1983). Interactions of the anticonvulsant carbamazepine with adenosine receptors. 1. Neurochemical studies. Epilepsia 24, 634-642.

Spealman, R. D. \& Coffin, V. L. (1986). Behavioral effects of adenosine analogs in squirrel monkeys: relation to adenosine $A_{2}$ receptors. Psychopharmacology 90, 419-421.

Stewart, S. F. \& Pugsley, T. A. (1985). Increase of rat serum prolactin by adenosine analogs and their blockade by the methylxanthine aminophylline Naunyn-Schmiedeberg's Archives of Pharmacology 331, 140-145.

Stone, T. W. (1981). Physiological roles for adenosine and adenosine 5'-triphosphate in the nervous system. Neuroscience 6, 523-555.

Stone, T. W. \& Perkins, M. N. (1979). Is adenosine the mediator of opiate action on neuronal firing rates? Nature 281, 227-228.

Stromgren, L. S. \& Boller, S. (1985). Carbamazepine in treatment and prophylaxis of manic-depressive disorder. Psychiatric Developments 3, 349-367.

Summers, W. K., Majovski, L. V., Marsh, G. M. \& Candelora, K. (1981). Use of THA in treatment of Alzheimer-like dementia; pilot study in twelve patients. Biological Psychiary 16, 145-153.

Summers, W. K., Viesselman, J. O., Marsh, G. M., Tachiki, K. \& Kling, A. (1986). Oral tetrahydroaminoacridine in the long-term treatment of senile dementia, Alzheimer type. New England Journal of Medicine 315, 1241-1245.

Swift, C. G. \& Tiplady, B. (1988). The effects of age on the response to caffeine. Psychopharmacology 94, 29-31.

Synder, S. H. \& Sklar, P. (1984). Behavioral and molecular actions of caffeine: focus on adenosine. Journal of Psychiatric Research 18, 91-106.

Synder, S. H., Katims, J. S., Annau, Z., Bruns, R. F. \& Daly, J. W. (1981). Adenosine receptors and the actions of the methylxanthines. Proceedings of the National Academy of Sciences, USA 78, 3260-3264.

Tamborska, E., Insel, T. \& Marangos, P. J. (1986). Peripheral and central type benzodiazepine receptors in Maudsley rats. European Journal of Pharmacology 126, 281-287.

Uhde, T. W. (1988). Caffeine: practical facts for the psychiatrist. In Anxiety: New Research Findings for the Clinician (ed. P. RoyByrne), pp. 73-98. American Psychiatric Press: Washington, DC.

Uhde, T. W., Boulenger, J.-P., Jimerson, D. C. \& Post, R. M. (1984). Caffeine: relationship to human anxiety, plasma MHPG and cortisol. Psy'chopharmacology' Bulletin 20, 426-430. van Calker, D., Muller, M. \& Hamprecht, B. (1979). Adenosine regulates via two different types of receptors the accumulation of cyclic AMP in cultured brain cells. Journal of Neurochemistry 33, 999-1005.

Vapaatalo, H., Onken, D., Neuronen, P. J. \& Westermann, E. (1975). Stereospecificity in some central circulatory effects of phenylisopropyladenosine PIA. Arzniemittel Forschung (Drug Research) 25, 407-410.

Veleber, D. M. \& Templer, D. I. (1984). Effects of caffeine on anxiety and depression. Journal of Abnormal Psychology 93, 120-122.

Virus, R. M., Baglajewski, T. \& Radulovacki, M. (1984). Circadian variation of $\left[{ }^{3} \mathrm{H}\right] \mathrm{N}^{6}$-(L-phenylisopropyl)adenosine binding in rat brain. Neuroscience Letters 46, 219-222.

Virus, R. M., Djuricic-Nedelson, M., Radulovacki, M. \& Green, R. D. (1983). The effects of adenosine and 2'-deoxycoformycin on sleep and wakefulness in rats. Neuropharmacology 22 1401-1404.

Wauquier, A., Van Belle, H., Van den Broeck, W. A. E. \& Janssen, P. A. J. (1987). Sleep improvement in dogs after oral administration of mioflazine, a nucleoside transport inhibitor. Psychopharmacology 91, $434-439$.

Weir, R. L., Padgett, W., Daly, J. W. \& Anderson, S. M. (1984). Interaction of anticonvulsant drugs with adenosine receptors in the central nervous system. Epilepsia 25, 492-498.

Weiss, S. R., Post, R. M., Marangos, P. J. \& Patel, J. (1985) Adenosine antagonists. Lack of effect on the inhibition of kindled seizures in rats by carbamazepine. Neuropharmacology 24, 635638 .

Williams, M. \& Jarvis, M. F. (1988). Adenosine antagonists as potential therapeutic agents. Pharmacology, Biochemistry and Behavior 29, 433-441.

Wojcik, W. J. \& Neff, N. H. (1983a). Differential location of adenosine $A_{1}$ and $A_{2}$ receptors in striatum. Neuroscience Letters 41, $55-60$.

Wojcik, W. J. \& Neff, N. H. (1983h). Location of adenosine release and adenosine $\mathrm{A}_{2}$ receptors to rat striatal neurons Life Sciences 33, 755-763.

Yanik, G. M., Glaum, S. \& Radulovacki, M. (1987). The doseresponse effects of caffeine on sleep in rats. Brain Research 403. $177-180$.

Yanik, G. M. \& Radulovacki, M. (1987). REM sleep deprivation upregulates adenosine $A_{1}$ receptors. Brain Research 402, 362-364.

Yarbrough, G. G. \& McGuffin-Clineschmidt, T. C. (1981). In vivo behavioral assessment of central nervous system purinergic receptors. European Journal of Pharmacology 76, 137-144.

Yeung, S. M. H. \& Green, R. D. (1984). ${ }^{3}[\mathrm{H}] 5^{\prime}$-N-ethylcarboxamide adenosine binds to both $R_{a}$ and $R_{\text {, }}$ adenosine receptors in rat striatum. Naunyn-Schmiedeberg's Archives of Pharmacology 325. 218-225. 